\title{
Effect of Aerva lanata against oxalate mediated free radical toxicity in urolithiasis
}

\author{
Vava Mohaideen Hazeena Begum ${ }^{1, *}$, Ramalingam Mahesh ${ }^{1}$, Thiyagarajan Ramesh ${ }^{1,2}$, and Periasamy \\ Soundararajan ${ }^{1,3}$
}

${ }^{1}$ Department of Siddha Medicine, Faculty of Science, Vakaiyur, Thanjavur-613005, Tamilnadu, India; ${ }^{2}$ Department of Pharmacology, School of Dentistry, Kyung Hee University, Seoul 130-701, South Korea; ${ }^{3}$ Department of Nephrology, Sri Ramachandra Medical College and Research Institute (Deemed University), 1, Ramachandra Nagar, Porur, Chennai - 600 116, India

\begin{abstract}
SUMMARY
This study was undertaken to evaluate the antioxidant potential of A. lanata on oxalate mediated free radical toxicity in ethylene glycol induced calcium oxalate urolithic rats. Calcium oxalate $(\mathrm{CaOX})$ stone was induced by $0.75 \%$ ethylene glycol in drinking water for 28 days. From $29^{\text {th }}$ day onwards, the $\mathrm{CaOX}$ urolithic rats were treated with $A$. lanata aqueous suspension $(2,000 \mathrm{mg} / \mathrm{kg}$ body weight/dose/day) orally for another 28 days. At the end of experimental periods the animals were sacrificed, samples were collected and analyzed the lipid peroxidation product, protein oxidation product, enzymatic and non-enzymatic antioxidants in normal and experimental groups. Lipid peroxidation and protein oxidation products were significantly elevated while enzymatic and non-enzymatic antioxidant levels were significantly decreased in ethylene glycol induced $\mathrm{CaOX}$ urolithic rats when compared with control rats. The above alterations were reverted to near control in rats treated with aqueous suspension of $A$. lanata. This study suggests that $A$. lanata could prevent the free radical formation from calcium oxalate urolithiasis in rats and protecting the renal cells from oxidative injury.
\end{abstract}

Keywords: Ethylene glycol; Urolithiasis; Free radical; Lipid peroxidation; Anti oxidant

\section{INTRODUCTION}

Urolithiasis or kidney stone formation is a complex process and involves a cascade of events, including crystal nucleation, growth and aggregation, retention with in the renal tubules, and migration to the renal papillary surfaces (Khan, 1995). Several types of stone has been forming in the kidney those stones are classified on the basis of chemical composition. Calcium oxalate stones are more

\footnotetext{
*Correspondence: Vava Mohaideen Hazeena Begum, Department of Siddha Medicine, Faculty of Science, Tamil University, Vakaiyur, Thanjavur - 613005, Tamilnadu, India. Tel: +914362227228; E-mail: drhazeenabiomed@yahoo.co.in
}

common, $70 \%$ to $80 \%$ of people suffering from this stones (Lewandowski and Rodgers, 2004). The metabolic products of ethylene glycol such as glycoaldehyde, glyoxylate, and oxalate cause oxidative stress induced tissue injury in the kidney. Exposure to oxalate has been shown to be toxic to renal epithelial cells, which results in lipid peroxidation mediated by free radicals (Thamilselvan et al., 2003). Formation of free radicals and reactive oxygen species (ROS) is a normal consequence of a variety of biochemical reactions. However, these free radicals are capable of independent existence and can cause oxidative damage to the tissues through lipid peroxidation (Cross et al., 1987). The 
human body has a natural synergistic and multilevel defense system, which contain two major classes of cellular protection against ROS (Muzakova et al., 2001). The enzymatic part is represented by free radical scavenger enzymes namely superoxide dismutase, catalase and glutathione peroxidase. The non-enzymatic part is vitamins, thiols etc., that have the ability to inhibit oxidative stress by scavenging the highly destructive free radical species. The harmful effects of the free radicals are kept under control by a delicate balance between the rate of their formation and the rate of their elimination by this defense mechanism (Halliwell, 1994). When there is an excessive addition of free radicals from exogenous sources added to the endogenous production, the available tissue defense system becomes overwhelmed resulting in oxidative damage to the tissues. When the normal level of antioxidant defense system is insufficient for the eradication of excessive free radicals, administration or supplementation of exogenous antioxidants has a protective role to play. Several antioxidants of natural origin have been experimentally proved as effective protective agents against free radical mediated oxidative stress (Castilla et al., 2006; Raghavan and Kumari, 2006; Vijayavel et al., 2006). In view of that A. lanata has been used against oxalate mediated free radical toxicity in urolithic rats.

Aerva lanata (L.) Juss. ex Schult. (Amaranthaceae) locally known as 'Siru peelai'. It is an erect or prostrate herbaceous weed, available in throughout the hotter parts of India almost all over the plains up to an altitude of $3,000 \mathrm{~m}$. A literature survey revealed that $A$. lanata is endowed with various bioactive components such as flavonoids, alkaloids, triterpenes, steroids, polysaccharides, tannins, saponins, etc (Chandra and Sastry, 1990; Afaq et al., 1991; Zapesochnaya et al., 1992), which possibly contribute to its diverse uses in folklore medicine. A. lanata is widely used in Indian traditional medicine for the treatment of a broad spectrum of ailments including cough, sore throat, wounds, headache, demulcent, gonorrhea, renal dysfunction, etc., Literature survey also reported about the therapeutic effects of A. lanata in kidney disorders (Ulluwisheva, 1991), diuretic and anti-inflammatory (Vetrichelvan et al., 2000), anti-diabetic (Vetrichelvan and Jegadeesan, 2002), antimicrobial (Chowdhury et al., 2002) and anti-tumor activity (Nevin and Vijayammal, 2003). Recently, our previous study has proved that $A$. lanata is a potent anti urolithic agent (Soundararajan et al., 2006). However, the present study was planned to further evaluation of the biopotency of A. lanata aqueous suspension on oxalate mediated oxidative stress in ethylene glycol induced urolithiasis in rats.

\section{MATERIALS AND METHODS}

\section{Plant material}

A. lanata fresh aerial parts were collected during the months of September to December in Tamil University, Thanjavur, Tamilnadu, India. The plant was identified, authenticated and deposited in the Herbarium, Tamil University. The aerial parts were dried thoroughly under shade and powdered finely. The powder was suspended in distilled water and used for the study.

\section{Animals \\ Male albino rats of Wistar strain weighing approximately 140 - $150 \mathrm{~g}$ were used. All animal experiments and maintenance were carried out according to the ethical guidelines suggested by the Institutional Animal Ethics Committee. Animals were housed in plastic cages with filter tops under controlled conditions of a $12 \mathrm{~h}$ light/12 h dark cycle, $50 \%$ humidity and $28^{\circ} \mathrm{C}$. All the rats received standard pellet diet (Amrut rat feed, Pune) and water ad libitum.}

\section{Stone induction}

Experimental urolithiasis was induced by $0.75 \%$ ethylene glycol in drinking water for 28 days ad libitum (Tamilselvan et al., 1997). After 28 days the 
urolithic rats were used for the study.

\section{Experimental Protocol}

In this experiment a total of 24 rats (12 urolithic rats, 12 normal rats) were used. The rats were divided into four groups of six rats each. Group 1: Control rats received only vehicle by using an intragastric tube for 4 weeks. Group 2: Normal rats received aqueous suspension of $A$. lanata alone (2,000 $\mathrm{mg} / \mathrm{kg}$ b.wt/dose/day) by using an intragastric tube for 4 weeks. Group 3: Urolithic rats received only vehicle by using an intragastric tube for 4 weeks. Group 4: Urolithic rats received aqueous suspension of A. lanata $(2,000 \mathrm{mg} / \mathrm{kg}$ b.wt/dose/day) by using an intragastric tube for 4 weeks.

At the end of experimental period all the animals were made fast over night and killed by decapitation after anaesthesia (Thiopentone sodium, $50 \mathrm{mg} /$ $\mathrm{kg}$ ). Blood was collected in heparinized tubes and plasma was separated. Kidneys were excised immediately and immersed in ice-cold physiological saline and blotted with filter paper. Known weight of tissues were homogenized in $0.1 \mathrm{M}$ tris- $\mathrm{HCl}$ buffer $\mathrm{pH} 7.4$ containing $0.25 \mathrm{M}$ sucrose and used for biochemical analysis.

\section{Biochemical analysis}

\section{Lipid and protein oxidation status}

The plasma and kidney homogenates were used for assaying the level of lipid peroxidation product, malondialdehyde (MDA) by Beuge and Aust (1978). The content of protein carbonyls (PCO) was determined by the method of Levine et al. (1990).

\section{Antioxidant status}

In the kidney, superoxide dismutase (SOD) activity was assayed by Kakkar et al. (1984). Catalase (CAT) activity was assayed by the method of Sinha (1972). Glutathione peroxidase (GPX) (Rotruck et al., 1973), glutathione reductase (GR) (Staal et al., 1969), glucose-6-phosphate dehydrogenase (G6PD) (Korenberg et al., 1955) and glutathione-s-transferase (GST)
(Habig et al., 1974) were also assayed. GSH was measured by the method of Moron et al. (1979). Vitamin C and E were assayed by Omaye et al. (1979) and Baker et al. (1980) respectively in plasma and kidney. Protein was estimated by the Lowry et al. (1951) method.

\section{Statistical analysis}

Values are mean \pm S.D. for six rats in the each group and statistical significant differences between mean values were determined by one way analysis of variance (ANOVA) followed by the Tukey's test for multiple comparison values of $P<0.05$ was considered to be significant. Statistical Package for Social Studies (SPSS) 7.5 version was used for this analysis.

\section{RESULTS}

Fig. 1 (A, B) and 2 (A, B) shows the concentrations of MDA and PCO in plasma and kidney of control and experimental rats. MDA and PCO levels were significantly elevated in calcium oxalate urolithic rats (Group III) when compared with control rats (Group I). A. lanata aqueous suspension supplement with calcium oxalate urolithic rats (Group IV) showed significant reduction in the levels of MDA and PCO when compared with untreated calcium oxalate urolithic rats (Group III). Significant changes were not observed in A. lanata aqueous suspension alone treated rats (Group II) as compared with control rats (Group I).

Table 1 expresses the activities of SOD, CAT, GP, GR, G6PD and GST in kidney of control and experimental rats. The activities of these antioxidant enzymes were significantly lowered in calcium oxalate urolithic rats (Group III) as compared to control rats (Group I). Aqueous suspension of $A$. lanata treatment with calcium oxalate urolithic rats (Group IV) showed significant amelioration in the activities of these enzymes when compared with untreated calcium oxalate urolithic rats (Group III). The activities of these antioxidant enzymes did not 

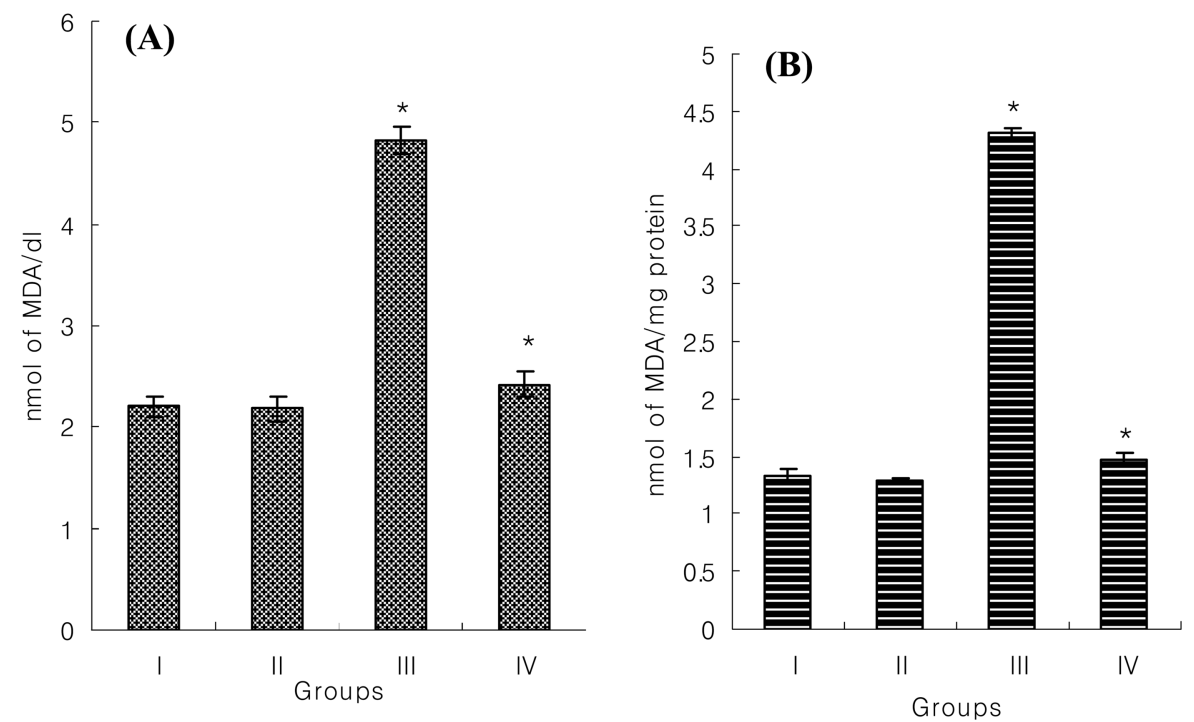

Fig. 1. Effect of A. lanata on MDA levels in experimental and control rats. (A) MDA levels in plasma were expressed as mean \pm S.D. $(n=6)$. Statistical comparison are made between Group I vs Group II and Group III; Group III vs Group IV. ${ }^{*} P<0.05$. (B) MDA levels in kidney were expressed as mean \pm SD $(n=6)$. Statistical comparison are made between Group I vs Group II and Group III; Group III vs Group IV. ${ }^{*} P<0.05$.

Table 1. Effect of A. lanata on antioxidant enzymes activities in kidney of control and experimental rats

\begin{tabular}{|c|c|c|c|c|c|c|}
\hline \multirow[b]{2}{*}{ Groups } & $\begin{array}{l}\text { Superoxide } \\
\text { dismutase }\end{array}$ & Catalase & $\begin{array}{l}\text { Glutathione } \\
\text { peroxidase }\end{array}$ & $\begin{array}{c}\text { Glutathione } \\
\text { reductase }\end{array}$ & $\begin{array}{l}\text { Glucose-6-phos- } \\
\text { phate dehydro- } \\
\text { genase }\end{array}$ & $\begin{array}{l}\text { Glutathione-s- } \\
\text { transferase }\end{array}$ \\
\hline & $\begin{array}{c}\text { (50\% reduction } \\
\text { of NBT/min/ } \\
\text { mg protein) }\end{array}$ & $\begin{array}{c}\left(\mathrm{mmol} \mathrm{H} \mathrm{O}_{2}\right. \\
\text { consumed/ } \\
\text { min/mg protein }\end{array}$ & $\begin{array}{c}\text { (mmole GSH } \\
\text { utilized/min/mg } \\
\text { protein) }\end{array}$ & $\begin{array}{l}\text { (nmol NADPH } \\
\text { oxidized/min/ } \\
\text { mg protein) }\end{array}$ & $\begin{array}{l}\text { (change in OD } \\
\text { of } 0.01 / \mathrm{min} / \\
\text { mg protein) }\end{array}$ & $\begin{array}{c}\text { (mmoles of } \\
\text { CDNB-GSH } \\
\text { conjugated/min/ } \\
\text { mg protein) }\end{array}$ \\
\hline Group I & $5.37 \pm 0.27$ & $32.4 \pm 1.73$ & $5.37 \pm 0.24$ & $0.24 \pm 0.03$ & $1.74 \pm 0.11$ & $0.74 \pm 0.03$ \\
\hline Group II & $5.39 \pm 0.27$ & $32.5 \pm 1.78$ & $5.38 \pm 0.32$ & $0.25 \pm 0.04$ & $1.79 \pm 0.09$ & $0.76 \pm 0.04$ \\
\hline Group III & $2.39 \pm 0.25^{*}$ & $13.6 \pm 1.33^{*}$ & $3.12 \pm 0.33^{*}$ & $0.11 \pm 0.03^{*}$ & $0.91 \pm 0.09^{*}$ & $0.40 \pm 0.04^{*}$ \\
\hline Group IV & $5.23 \pm 0.31^{*}$ & $29.4 \pm 1.47^{*}$ & $5.27 \pm 0.17^{*}$ & $0.20 \pm 0.04^{*}$ & $1.62 \pm 0.02^{*}$ & $0.73 \pm 0.05^{*}$ \\
\hline
\end{tabular}

Values are expressed as mean \pm S.D. $(n=6)$. Statistical comparison are made between Group I vs Group II and Group III; Group III vs Group IV. ${ }^{*} P<0.05$

show any significant changes in A. lanata aqueous suspension alone treated rats (Group II) as compared to control rats (Group I).

Table 2 and 3 represents the concentration of $\mathrm{GSH}$, vitamin $\mathrm{C}$ and vitamin $\mathrm{E}$ in plasma and kidney of control and experimental rats. GSH, vitamin $\mathrm{C}$ and vitamin E levels were significantly decreased in calcium oxalate urolithic rats (Group III) as compared with control rats (Group I).
Administration of aqueous suspension of $A$. lanata has brought the levels of GSH, vitamin $C$ and vitamin $E$ to near control in calcium oxalate urolithic rats (Group IV) when compared with untreated calcium oxalate urolithic rats (Group III). $\mathrm{GSH}$, vitamin $\mathrm{C}$ and vitamin $\mathrm{E}$ levels were not significantly altered in $A$. lanata aqueous suspension alone treated rats (Group II) as compared to control rats (Group I). 
Table 2. Effect of $A$. lanata on non-enzymatic antioxidants in plasma of control and experimental rats

\begin{tabular}{cccc}
\hline Groups & GSH $(\mathrm{mg} / \mathrm{dl})$ & Vitamin-C $(\mathrm{mg} / \mathrm{dl})$ & Vitamin-E $(\mathrm{mg} / \mathrm{dl})$ \\
\hline Group I & $34.53 \pm 2.42$ & $2.58 \pm 0.07$ & $6.04 \pm 0.47$ \\
Group II & $34.97 \pm 2.45$ & $2.54 \pm 0.12$ & $6.12 \pm 0.22$ \\
Group III & $19.27 \pm 0.96^{*}$ & $1.32 \pm 0.09^{*}$ & $3.15 \pm 0.43^{*}$ \\
Group IV & $30.26 \pm 1.82^{*}$ & $2.44 \pm 0.03^{*}$ & $5.96 \pm 0.42^{*}$ \\
\hline
\end{tabular}

Values are expressed as mean \pm S.D. $(n=6)$. Statistical comparison are made between Group I vs Group II and Group III; Group III vs Group IV. ${ }^{*} P<0.05$

Table 3. Effect of A. lanata on non-enzymatic antioxidants in kidney of control and experimental rats

\begin{tabular}{cccc}
\hline Groups & GSH $(\mu \mathrm{g} / \mathrm{mg}$ protein $)$ & Vitamin-C $(\mu \mathrm{g} / \mathrm{mg}$ protein $)$ & Vitamin-E $(\mu \mathrm{g} / \mathrm{mg}$ protein $)$ \\
\hline Group I & $2.46 \pm 0.12$ & $2.37 \pm 0.11$ & $1.97 \pm 0.02$ \\
Group II & $2.48 \pm 0.15$ & $2.41 \pm 0.12$ & $2.07 \pm 0.04$ \\
Group III & $1.43 \pm 0.07^{*}$ & $1.05 \pm 0.04^{*}$ & $0.94 \pm 0.05^{*}$ \\
Group IV & $2.14 \pm 0.11^{*}$ & $2.34 \pm 0.07^{*}$ & $1.88 \pm 0.03^{*}$ \\
\hline
\end{tabular}

Values are expressed as mean \pm S.D. $(n=6)$. Statistical comparison are made between Group I vs Group II and Group III; Group III vs Group IV. ${ }^{*} P<0$.
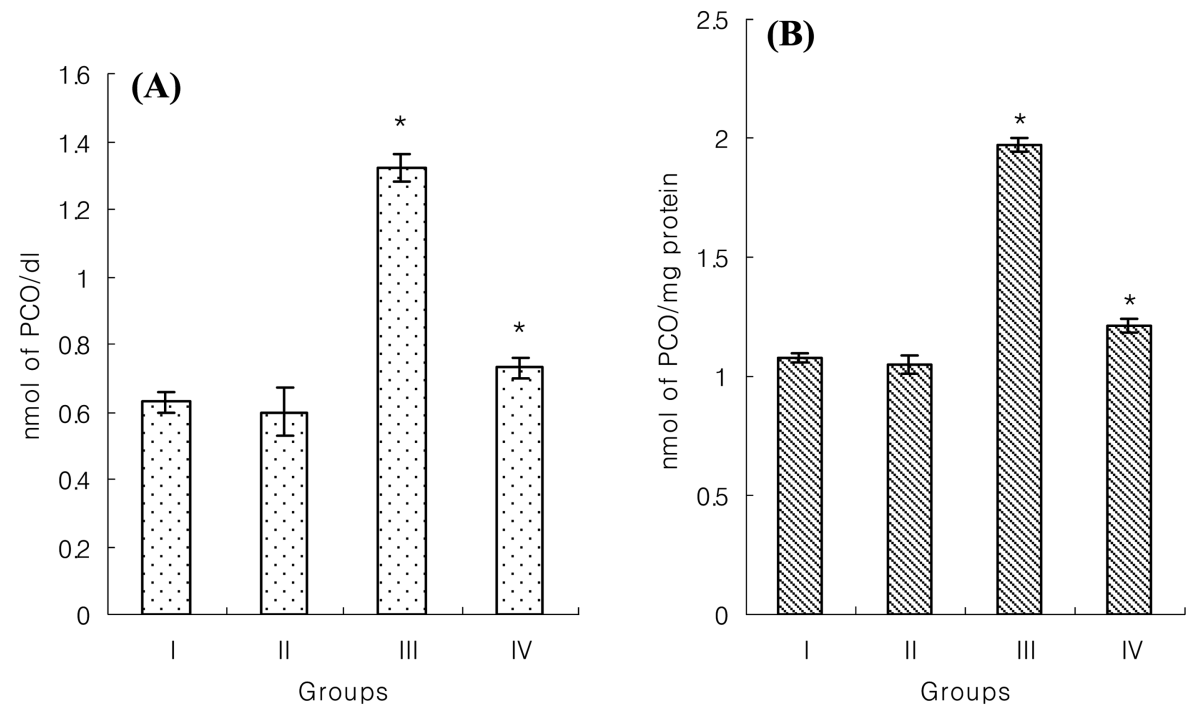

Fig. 2. Effect of A. lanata on PCO levels in experimental and control rats. (A) PCO levels in plasma were expressed as mean \pm S.D. $(n=6)$. Statistical comparison are made between Group I vs Group II and Group III; Group III vs Group IV. ${ }^{*} P<0.05$. (B) PCO levels in kidney were expressed as mean \pm S.D. $(\mathrm{n}=6)$. Statistical comparison are made between Group I vs Group II and Group III; Group III vs Group IV. ${ }^{*} P<0.05$.

\section{DISCUSSION}

The experimental evidence of this study depicted that calcium oxalate crystal reduced the antioxidant levels and increased MDA content and protein carbonyl in rats in ethylene glycol induced urolithiasis. The significant increase in lipid peroxidation and protein carbonyl content in rats in group III with calcium oxalate stone is in agreement with the previous report (Thamilselvam and Menon, 2005). The increased lipid peroxidation and protein carbonyl in the rat in urolithiasis indicates that antioxidant deficiency potentiates the oxalate induced free-radical production in the 
kidney. Grases et al. (1998) reported that free radical-damaged cells produce a favorable environment for crystal development, and that phytic acid prevents calcium oxalate crystallization by its antioxidant properties. Recent studies show increased urinary excretion of MDA in human calcium-oxalate kidney stone formers (Huang et al., 2003). In addition, another recent study provided more evidence indicating that oxidative stress plays a major role in human calcium oxalate kidney stone formation (Tungsanga et al., 2005). The authors also reported increased MDA, decreased Vitamin E, GSH, and GPx activity in human kidney stone formers (Tungsanga et al., 2005), which is similar to the levels observed in our present study with the rat model. The present results clearly show that supplementation of aqueous suspension of $A$. lanata significantly decreased oxalate-induced lipid peroxidation and protein oxidation by ameliorating antioxidant levels. This observations consistent with previous report that antioxidant may have a protective effect against free-radical injury associated with oxalate treatment (Thamilselvam et al., 2003).

In the present study antioxidant enzymes such as SOD, CAT, GR and GPx activities were decreased in urolithic rats. These results are comparable with earlier reports (Thamilselvam and Menon, 2005; Rajeswari and Varalakshmi, 2006). The significant decreases in SOD and CAT activities were attributed to accumulation of $\mathrm{O}_{2}^{-}$ and $\mathrm{H}_{2} \mathrm{O}_{2}$ which in turn forms the hydroxyl radicals $(\mathrm{OH})$ in oxidative stress caused by increased calcium oxalate crystal in the renal tissues (Selvam and Bijikurien, 1987; Selvam Bijikurien, 1991). Diminished activity of $\mathrm{GP}_{x}$ correlated with decreased availability of its substrate reduced glutathione as well as increased free radicals in urolithic rats (Srinivasan et al., 2004). GR activity also decreased in urolithic rats, this might be attributed to the excessive production of oxidized glutathione, which fails to match the capacity of GR, and to reduce oxidized glutathione (Sen et al., 1993). In addition, the activity of G6PD and GST were decreased in ethylene glycol induced urolithic rats. G6PD is used to regenerate reduced glutathione, which scavenges $\mathrm{H}_{2} \mathrm{O}_{2}$ and GST catalyzes the transformation of peroxides to less toxic products conjugating them to reduced glutathione (Sun, 1990). The diminished activities of G6PD and GST indicate that ethylene glycol induced calcium oxalate significantly decreased plasma and renal GSH level. However, the greatest depletion of GSH in group III rats suggests tissue antioxidant imbalance. In addition, the decrease in GR and G6PD indicates impaired reduction of oxidized glutathione to GSH by depletion of reducing equivalent of NADPH, which is a cosubstrate for GR activity (Malini et al., 2000). Vitamin E and C act synergistically through the interactions between lipid and water soluble substances by both enzymatic and non-enzymatic mechanisms to confer protection in tissues against oxidative damage (Anand et al., 1992). The levels of these vitamins were also found to be reduced drastically in calcium oxalate urolithic (group III) rats. The losses of these vitamins virtually depict the extent of potential peroxidative assault rendered by increased concentration of oxalate in the kidney. Supplementation of aqueous suspension of A. lanata contributed to maintaining the antioxidants at an optimum level by protecting renal tubules from peroxidative injury. These results confirm that $A$. lanata acts as an excellent antioxidant for the kidney, which is greatly susceptible to oxalate-induced free radical damage.

In conclusion, these findings depict novel and direct evidence in vivo that calcium oxalate induced peroxidative damage to the renal tubular membrane surface provides a favorable environment for individual calcium oxalate crystal attachment and subsequent development of kidney stones. Aqueous suspension of $A$. lanata treatment can prevent calcium oxalate crystal deposition in the kidney, by preventing calcium oxalate induced lipid peroxidation, protein oxidation and tissue antioxidant imbalance. From these findings, A. lanata could therefore be 
considered in the therapy of calcium oxalate induced kidney stone formation, and this could benefit individuals with recurrent kidney stone disease.

\section{REFERENCES}

Afaq SH, Tajuddin S, Afridi R. (1991) Bisheri Booti (Aerva lanata) some lesser known uses and pharmacognosy. Ethnobotany. 5, 37-40.

Anand R, Patnaik GK, Kulshreshtha DK, Dhawan BN. (1992) Antiurolitiatic and diuretic activity of Lupeol, the active constituent isolated from Crataeva nurvala (Buch Ham). Indian J. Pharmacol. 24, 48-49.

Baker H, Frank O, De Angeles B, Feinglod S. (1980) Plasma tocopherol in man at various times after ingesting free or acetylated tocopherol. Nutr. Rep. Int. 21, 531-537

Beuge JA, Aust SD. (1978) The thiobarbituric acid assay. Meth. Enzymol. 52, 306-307.

Castilla P, Echarri R, Davalos A, Cerrato F, Ortega H, Teruel JL, Lucas MF, Gomez-Coronado D, Ortuno J, Lasuncion MA. (2006) Concentrated red grape juice exert antioxidant, hypolipidemic, and anti-inflammatory effects in both hemodialysis patients and healthy subjects. Am. J. Clin. Nutr. 84, 252-262.

Chandra S, Sastry MS. (1990) Chemical constituents of Aerva lanata. Fitoterapia 61, 188-190.

Chowdhury D, Sayeed A, Islam A, Bhuiyan MSA, Khan GRMAM. (2002) Antimicrobial activity and cytotoxicity of Aerva lanata. Fitoterapia 73, 92-94.

Cross CE, Halliwell B, Borish ET, Pryor W, Ames BN, Saul RL, McCord JM, Harman D. (1987) Oxygen radicals and human disease. Ann. Intern. Med. 107, 526-545.

Grases F, Garcia-Ferragut L, Costa-Bauza A. (1998) Development of calcium oxalate crystals on urolithium: effect of free radicals. Nephron 78, 296-301.

Habig WH, Pabst MJ, Jakpoby WB. (1974) GST, a first enzymatic step in mercapturic acid formation. J. Biol. Chem. 249, 7130-7139.

Halliwell B. (1994) Free radicals, antioxidants, and human disease: curiosity, cause, or consequence? Lancet 344, 721-724.

Huang HS, Ma MC, Chen CF, Chen J. (2003) Lipid peroxidations and its correlations with urinary levels of oxalate, citric acid, and osteopontin in patients with renal calcium oxalate stones. Urology 62, 1123-1128.

Kakkar P, Das B, Viswanathan PN. (1984) A modified spectrophotometric assay of SOD. Indian J. Biochem. Biophys. 21, 130-132.

Khan SR. (1995) Animal model of calcium oxalate nephrolithiasis. In: Caicium oxalate in biological systems, edited by Khan SR, pp. 343-359, CRC Press. Boca Raton, FL.

Korenberg A, Horecker BL, Horecker BL, Smyrniotis PZ. (1955) Glucose-6-phosphate dehydrogenase 6phospho-gluconic dehydrogenase. Meth. Enzymol. 1, 323-327.

Levine RL, Garland D, Oliver CN, Amici A, Lenz AZ, Ahn B, Shaltiel S, Stadtman ER. (1990) Assay of carbonyl in protein. Meth. Enzymol. 186, 464-478.

Lewandowski S, Rodgers AL. (2004) Idiopathic calcium oxalate urolithiasis: risk factors and conservative treatment. Clin. Chim. Acta 345, 17-34.

Lowry OH, Rosenbrough NJ, Farr AL, Randall RJ. (1951) Protein measurement with the Folin's reagent. J. Biol. Chem. 193, 265-276.

Malini MM, Lenin M, Varalakshmi P. (2000) Protective effect of triterpenes on calcium oxalate crystal-induced peroxidative changes in experimental urolithiasis. Pharmacol. Res. 41, 413-418.

Moron MS, Defierre JW, Mannervik B. (1979) Levels of glutathione, glutathione reductase, glutathiones-transferase activities in rat lung and liver. Biochim. Biophys. Acta 582, 67-78.

Muzakova V, Kandar R, Vojtisek P, Skalicky J, Vankova R, Cegan A, Cervinkova Z. (2001) Antioxidant vitamin levels and glutathione peroxidase activity during ischemia/reperfusion in myocardial infarction. Physiol. Res. 50, 389-396.

Nevin KG, Vijayammal PL. (2003) Effect of Aerva lanata on solid tumor induced by DLA cells in mice. Fitoterapia 74, 578-582.

Omaye ST, Tumball JD, Sauberlich HE. (1979) Selected methods for the determination of ascorbic acid in animal cells, tissues and fluids. Meth. Enzymol. 62, 1-11.

Raghavan B, Kumari SK. (2006) Effect of Terminalia arjuna stem bark on antioxidant status in liver and kidney of alloxan diabetic rats. Indian J. Physiol. Pharmacol. 50, 133-142. 
Rajeswari A, Varalakshmi P. (2006) Low molecular weight heparin protection against oxalate-induced oxidative renal insult. Clin. Chim. Acta 370, 108-114.

Rotruck JT, Pope AL, Ganther HE, Swanson AB, Hafeman DG, Hoekstra WG. (1973) Selenium: biochemical roles as component of glutathione peroxidase. Science 179, 588-590.

Selvam R, Bijikurien T. (1987) Induction of lipid peroxidation by oxalate in experimental rat urolithiasis. J. Biosci. 12, 367-373.

Selvam R, Bijikurien T. (1991) Methionine feeding prevents kidney stone deposition by restoration of free radical mediated changes in experimental rat urolithiasis. J. Nutr. Biochem. 2, 644-651.

Sen CK, Rahkila P, Hanninen O. (1993) Glutathione metabolism in skeletal muscle derived cells of the L6 line. Acta Physiol. Scand. 148, 21-26.

Sinha AK. (1972) Colorimetric assay of catalase. Anal. Biochem. 47, 389-394.

Soundararajan P, Mahesh R, Ramesh T, Hazeena Begum V. (2006) Effect of Aerva lanata on calcium oxalate urolithiasis in rats. Indian J. Exp. Biol. 44, 981-986.

Srinivasan S, Pragasam V, Jenita X, Kalaiselvi P, Muthu V, Varalakshmi P. (2004) Oxidative stress in urogenital tuberculosis patients: a predisposing factor for renal stone formation-amelioration by vitamin E supplementation. Clin. Chim. Acta 350, 57-63.

Staal GEJ, Visser J, Veeger C. (1969) Purification and properties of glutathione reductase of human erythrocytes. Biochim. Biophys. Acta 185, 39-48.

Sun Y. (1990) Free radicals, antioxidant enzymes, and carcinogenesis. Free Radic. Biol. Med. 8, 583-599.
Tamilselvan S, Hackett RL, Khan SR. (1997) Lipid peroxidation in ethylene glycol induced hyperoxaluria and calcium oxalate nephrolithiasis. J. Urol. 157, 1059-1063.

Thamilselvam S, Menon M. (2005) Vitamin E therapy prevents hyperoxaluria-induced calcium oxalate crystal deposition in the kidney by improving renal tissue antioxidant status. B. J. U. Int. 96, 117-126.

Thamilselvan S, Khan SR, Menon M. (2003) Oxalate and calcium oxalate mediated free radical toxicity in renal epithelial cells: effect of antioxidants. Urol. Res. 31, 3-9.

Tungsanga K, Sriboonlue P, Futrakul P, Yachantha C, Tosukhowong P. (2005) Renal tubular cell damage and oxidative stress in renal stone patients and the effect of potassium citrate treatment. Urol. Res. 33, 65-69.

Ulluwisheva RK. (1991) Modernisation versus sustainability. Environ. Conserv. 18, 103-109.

Vetrichelvan T, Jegadeesan M, Senthil Palaniappan M, Murali NP, Sasikumar K. (2000) Diuretic and anti-inflammatory activities of Aerva lanata in rats. Indian J. Pharm. Sci. 4, 300-305.

Vetrichelvan T, Jegadeesan M. (2002) Anti-diabetic activity of alcoholic extract of Aerva lanata (L.) Juss. ex Schultes in rats. J. Ethnopharmacol. 80, 103-107.

Vijayavel K, Anbuselvam C, Balasubramanian MP. (2006) Free radical scavenging activity of the marine mangrove Rhizophora apiculata bark extract with reference to naphthalene induced mitochondrial dysfunction. Chem. Biol. Interact. 163, 170-175.

Zapesochnaya GG, Okhanov V, Kurkin V, Kiroshnikov A. (1992) Cathine-6-one and beta carboline alkaloids from Aerva lanata. Planta Med. 37, 192-196. 